\title{
Bosnia and Herzegovina: The Proximate Colony in the Twilight of Empire
}

\author{
Robert J. Donia \\ Ann Arbor
}

Under Austro-Hungarian administration (18781918), Bosnia and Herzegovina $(\mathrm{BiH})$ became the locus of the Habsburg Monarchy's colonial and geostrategic ambitions in the Balkans. ${ }^{1}$ But what kind of a colony was this, one which adjoined its parent colonizer along two-thirds of its boundaries? In this essay, I argue that BosniaHerzegovina during its Habsburg era may best be understood as a proximate colony, in which the proximity of colony and colonizer compounded what Georges Balandier called, in his landmark 1951 essay, its "colonial situation".

Following the American historian of Africa, Frederick Cooper, ${ }^{3}$ I argue that colonialism in $\mathrm{BiH}$, more than just a legal characterization or the repressive hegemony of one society over another, often produced unforeseen changes in the societies of both the colony and the colonizing power (here called the metropole, following conventions in the literature). Characterizing $\mathrm{BiH}$ as a "proximate colony" draws upon the historical reinterpretation known as the Imperial Turn, which questions the long-accepted differentiation between nation-states (which are viewed as modern and progressive) and empires (which are seen as archaic and dysfunctional). One scholar of the British Empire defines the imperial turn as "accelerated attention ... [to] metropolitan societies" [that is, the imperializing homelands] in histories of imperialism. ${ }^{4}$ I will apply the rein-

\footnotetext{
${ }^{1}$ Austro-Hungarian strategic interests in Bosnia-Herzegovina are explained in Kraljačić 1987, 13-38.

${ }^{2}$ Balandier 1951, 44-79; Balandier 1966, 34-81.

${ }^{3}$ Cooper 2005, 33-55.

${ }^{4}$ In full, "We take 'the imperial turn' to mean the accelerated attention to the impact of histories of colonialism on metro-
}

terpretations of the Imperial Turn to Bosnia and Herzegovina in three areas: economic relations, nationality issues, culture.

\section{Economic Relations}

Economically, the Monarchy's officials mainly treated its colony much like other European powers treated their overseas colonial holdings: They imported raw materials from it and exported manufactured goods to it. But two factors made economic relations between the metropole and colony unique: the intense rivalry between Hungary and Cisleithanian Austria for domination of the Bosnian market, and the proximity of colonizer and colony. The various elements of the economic rivalry have been ably described and analyzed in several works of Academic Dževad Juzbašić, each firmly grounded in thorough archival research. I risk greatly oversimplifying his carefully nuanced conclusions, but in summary, I believe he has amply demonstrated that the rivalry seriously impeded economic progress in $\mathrm{BiH}$. The rivalry retarded infrastructure development (particularly railroad building), led to politically-motivated investments and capital allocation, impeded the development of free markets, and entailed policies that inhibited domestic industry while subsidizing manufacturing in both halves of the Monarchy.

The triangular-shaped territory of Bosnia and Herzegovina jutted deeply into Hungarian holdings and Croat-inhabited lands. For manyin the

politan societies in the wake of decolonization..." Burton 2003, 2 . 
metropole, it was easier and less costly to cross Bosnia than go around it, rendering Bosnia's infrastructure subordinate to the interests of neighbors rather than a facilitator of domestic economic growth.

The Hungarian part of the Monarchy enjoyed the greater proximity to the new colony, as Bosnian territory bordered lands of the Hungarian crown far more than Austria. Proximity gave Hungary a natural advantage over Austria that resulted over time in greater Hungarian domination of Bosnian policies and markets. Hermann von Sauter, legal advisor to the Vienna Chamber of Commerce, wrote an informative report in 1910 that was brought to light and analyzed by Akademik Dževad Juzbašić. ${ }^{5}$ The report suggests a three-corner relationship among Austria, Hungary, and $\mathrm{BiH}$, in which tensions over Bosnia further polarized the Monarchy's two halves. His report is principally an appeal for business leaders in the Austrian half to overcome the Hungarian advantage by stressing the cultural and ethnic (i.e., Slavic) ties between the Austrian lands and Bosnia.

Indeed, it is both valid and productive to think of the relationship as tripartite, with the interaction between any two parties affecting the third. Such a conceptualization allows us to see clearly the profound importance of proximity in facilitating economic exploitation to the benefit of the stronger party. Such a tripartite relationship rarely existed in other colonial situations.

\section{Remaking Culture and its Repercussions in the Metropole}

Habsburg officials hoped to win the battle for Bosnia through a sustained campaign to spread imperial culture and wean the populace away from the appealing nationalism infiltrating $\mathrm{BiH}$ from adjacent lands. But they faced a dilemma: They wanted to spread the blessings of western technology and culture to its new colony while upholding its conservative social structure and keeping its residents docile and content. The administrators found a way to do this by finding deep historical models to legitimize their own

\footnotetext{
5 "Izvještaj Hermanna von Suatera o odnosima Bosne i Hercegovine i Monarhije u svjetlu Austrougarskih ekonomskih suprotnosti," in Juzbašić 2002, 87-139.
}

ambitions. Today I will discuss three such cultural promotions: the promotion of Bosnian local patriotism; the embrace of Roman Imperial culture; and the regime's multifaceted relationship with the Viennese Secession.

In the best known of these initiatives, Kallay and his army of administrators sought to advance local patriotism through the distinctly Bosnian identity of Bošnjaštvo. To promote Bošnjaštvo, Habsburg officials (led by Benjamin Kallay) established institutions of research to uncover the unique Bosnian past. They established durable scientific institutions (particularly the Landesmuseum / Zemaljski muzej) and launched successful efforts to increase understanding of Bosnia's history, geography, and human diversity. Though the campaign for Bošnjaštvo failed spectacularly, the institutions established to support the campaign proved valuable and durable contributions to Bosnian culture. These included institutions of learning, research, and memory, an indigenous history, and the further development of a "western face" that made Bosnia a bridge between east and west rather than a solely a zone of confrontation.

These efforts reverberated in the Monarchy itself and beyond, in ways not yet fully understood by historians. The cultural "blowback" from Bosnia to the Monarchy offers potential for fruitful investigation by scholars of several disciplines, including cultural historians. To be sure, Bosnia's real and imagined colonial situation found a prominent place in the pavilions of several international exhibits. The cultural campaign for local patriotism offended nationalists both in Bosnia and the Monarchy, but it nourished a sense of Habsburg exceptionalism that further whetted the ambitions of imperial officials for expansion and eventually conquest.

In a second initiative, the Habsburg authorities sought to justify and glorify their administration successes, in part by contrasting them with the disorder and contention they believed had characterized Ottoman administration that they had displaced. They found precedent for their efforts in the imperial culture of ancient Rome. Having held the crown of the Holy Roman Empire of the German Nation for centuries until it was abolished in 1808, the Habsburg rulers saw themselves as successors to the Roman Emperors. Ruins from Roman times were scattered across Bosnia, reminiscent of the time 
when much of Europe and Southeast Europe were part of a common imperial behemoth. The Habsburg administrators made it their business to find and valorize those ruins, through archaeological expeditions sponsored by the Zemaljskimuzej and institutions from elsewhere in the Monarchy. In memorial politics, Habsburg bureaucrats privileged ancient Rome, known for its administrative efficiency, powerful emperor, and centralized rule, over ancient Greece, birthplace of individualism and the democracy. They also co-opted existing structures for their cause by falsely labeling them as Roman, most notably the architectural serenity of the Ottoman-era bridge across the Neretva in Mostar. This element of Habsburg cultural imperialism is little studied but deserves greater attention, as well as its reverberations in the metropole.

Finally, the Habsburg imperialists embraced only slowly and partially the movement known in Vienna as the Secession and elsewhere as Art Noveau and Art Deco, among other titles. The secession privileged beauty, elegant complexity, and nature-based decorative motivs over symbols of power and politics. It was ragingly popular in the early 1900's in Vienna, but as elsewhere in the Monarchy, the authorities in $\mathrm{BiH}$ considered it inappropriate for public and official structures. They favored instead the neo-historical styles on display in Vienna's Ringstrasse that had dominated the Monarchy's official structures since the 1860s.

But as with local patriotism and modern administration, the authorities found a way to capture a version of the Secession that incorporated Bosnian traditions. Officially-sponsored manufacturers incorporated local designs (many of them imagined or invented) into carpets and handicrafts. Folk motivs blended with Secessionist floral patterns to valorize and idealize the Bosnian past while generating jobs and capital in the factories, workshops, and domestic production facilities in or near Bosnia's largest towns.

I conclude that Habsburg Orientalism in Bosnia contributed to a makeover of the Monarchy's image at home and abroad and its greater selfconfidence as a European power. At the various expositions and world fairs of the late nineteenth century, Bosnia was showcased as a success of the Monarchy's colonial mission, a wild land that the Monarchy's officials tamed, explored, described, exploited, developed, and civilized. The natives appeared docile and content in these representations, much like those of colonial peoples in other parts of the world. The Monarchy emerged in these exhibits as renewed, robust, and successful in bringing order and tranquility to savage eastern lands. The repercussions of imperialism in the metropole are evident in the greater self-confidence and superiority embedded in the Secessionist adoption of Bosnian motivs in the early twentieth century.

\section{Intensifying national polarization}

During the era of Habsburg rule, national contention intensified in both the metropole and the colony. The "national question," it turned out, was a question that had no possible answer; it wasan existential dilemma rather than a problem subject to being solved. And any compromise would leave all parties sufficiently disappointed that they were bound to renew and intensify their internecine strife.

Bosnia's proximity to the metropole exacerbated tensions among already-contending national movements: Proximity raised the stakes, increased the number of stakeholders, and widened the divisions among them. Two of the most vital centers of Croat and Serb national activity of Croats and Serbs were both inside the Monarchy: Zagreb for Croats, and Novi Sad for Serbs. The pre-1878 borders between Bosnia (strictly speaking, the Ottoman Empire) and its neighbors overnight became internal boundaries when the Imperial Army occupied Bosnia and the Monarchy's civil servants administered it. Emissaries and dignitaries from Serb- and Croat-inhabited parts of the Monarchy found it relatively easy to travel to $\mathrm{BiH}$ (though usually under surveillance, particularly during the Kallay era) to provide legal and ideological guidance to their co-nationals.

Relations between nations proceeded quite differently in the Bosnian colony and in the Habsburg metropole. In the metropole, political parties had already been formed by 1878 and were rapidly proliferating, complicating the task of reaching a national accommodation compatible with the preservation of the Monarchy. The national movements in Bosnia, on the other hand, were embryonic when the occupation began in 1878 , and the formation of nationally-based po- 
litical parties was still more than two decades away. But during Habsburg rule, the national communities in Bosnia and Herzegovina gained consciousness and developed culturally and politically, largely by assimilating the practices and organizational structure of communities in the metropole. In the last years of Habsburg rule, the "national question" in the colony and in the metropole combined to become one, putting the entire Monarchy at risk because of developments in Bosnia and Herzegovina.

The number of Slavs in the empire grew with the acquisition of the Bosnia colony. As a result, Slavs throughout the empire raised their hopes for creation of a third, Slavic element in the Monarchy, equal in influence and power with Germandominated Cisleithania and the lands of the Hungarian crown. Hungarians correspondingly felt threatened. They wished to lead one of two parts, not one of three, and as landed agrarians, leading Hungarian politicians they feared losing influence to the more industrially developed parts of the Monarchy. In short, the Habsburg acquisition of Bosnia's Slavs greatly complicated and intensified national competition throughout the realm.

The proximity of $\mathrm{BiH}$ to the Monarchy also stimulated growth of the social and technological foundations of modern national movements. Many scholars have argued that the "colonial situation" inadvertently facilitated the growth of political movements in the colonyby promoting education, group self-awareness, technology, and modern systems of communication and transportation. All these developments allowed the colonized to mobilize more effectively, to offer various types of resistance to the colonizer and to compete vigorously with one another. Economic development also facilitated the embryonic origins of a literate professional class that become the chief carrier of national resistance to colonial rule. Owing to proximity, political entrepreneurs in the metropole found ample opportunities to transmit techniques for organizing politically and for managing the diverse views and interests within their movements.

\section{Conclusion}

By viewing Bosnia during the Habsburg era as a proximate colony, we can reconceptualize the relationship between the Monarchy as metropole and its proximate colonyas dynamic and interdependent. I have urged a scholarly re-examination of several of these relationships, in the conviction that the complex and evolving relationship between the two may productively be viewed as between colonizer and colony in a number of areas beyond legally-based characterizations of the relationship. I am confident that rethinking these relationships with an eye toward mutual interdependency and reciprocity will lead to a broader, richer, and better contextualized understanding of these particularly influential forty years of Bosnia's history.

\section{Rezime}

\section{Bosna i Hercegovina: bliska kolonija u sumraku carstva}

Pod austrougarskom upravom 1878-1918, Bosna i Hercegovina je postala prostor austrougarskih geostrateških ambicija na Balkanu. Ali kakav je to oblik kolonije koji svog kolonizatora dotiče dvjema trećinama svojih granica? U ovom radu tvrdim da se Bosna i Hercegovina u doba Habsburške ere najbolje može shvatiti kao bliska kolonija, gdje blizina kolonije i kolonizatora tvori, kako to Georges Balandier u svome eseju iz 1951. godine naziva, "kolonijalnu situaciju". Slijedeći Fredericka Coopera, američkog istoričara koji se bavio Afrikom, pokazujem da kolonijalizam u $\mathrm{BiH}$ nije samo represivna hegemonija jednog društva nad drugim, nego je često uzrokovao i nepredviđene promjene u društvima, kako u koloniji, tako i u kolonizirajućoj sili. Označavanje BiH kao "bliske kolonije" povlači za sobom i rekapitulaciju carstva u povijesnom kretanju poznatom kao Carski obrat i preispituje prevladavajuće naučne modele koji jasno odvajaju "moderne" nacije-države i pretpostavljene arhaične i disfunkcionalne imperijalne strukture.

\section{Literatura}

Balandier, G. 1951, La situation coloniale. Approche théorique, In: Cahiers Internationaux de Sociologie 11, 1951.

Balandier, G. 1966, Social Change. The Colonial Situation, English trans. in Wallerstein, I. (Ed.), Wiley, New York 1966, 34-81. 
Burton, A. (Ed.) 2003, After the Imperial Turn: Thinking with and through the Nation, Duke University Press, Durham 2003.

Cooper, F. 2005, Colonialism in Question. Theory, Knowledge, History, California UP, Berkeley 2005. Juzbašić, Dž. 2002, Politika i privreda u Bosni i Hercegovini pod Austrougarskom upravom, Posebna izdanja ANUBiH CXVI, Odjeljenje društvenih nauka 35, Sarajevo 2002.

Kraljačić, T. 1987, Kalajev režim u Bosni i Hercegovini 1882-1903 [Kállay's Regime in Bosnia and Hercegovina 1882-1903], Veselin Masleša, Sarajevo 1987. 
